\title{
THE WELDABILITY OF THE STEEL WITH HIGH MANGANESE
}

\author{
Eva Schmidova, Ivo Hlavaty, Petr Hanus
}

Original scientific paper Nowadays one of the most important parts, which are used in railway industry, are crossings, and principally the dynamic component of the operation exposures. A Mangalloy, also called as manganese steel or Hadfield steel, is a steel with alloys containing an average $13 \%$ of manganese and is unique for the reason that it combines high toughness and ductility with great work-hardening capacity. The wear resistance before the contact wear depends on the level of the surface hardening intensity, and the hardening process during operation consequently [1, 2, 3]. As abrasion resistance is proper to increase the carbon level above $1,4 \%$ and moreover, it could cause a problem in obtaining a homogenous austenitic structure which would be sufficiently free of carbide bordered grains [4].

Keywords: manganese steel; railway; weldability

\section{Zavarljivost čelika s visokim udjelom mangana}

Izvorni znanstveni članak Jedan od najvažnijih dijelova koji se danas koriste na željeznici su dijelovi na cestovnim prijelazima preko pruge i uglavnom dinamička komponenta izložena djelovanju. Mangalloy, također poznat kao čelik s manganom ili Hadfield čelik, je čelik s legurama koje u prosjeku sadrže 13 \% mangana i jedinstven je po tome što povezuje visoku žilavost i duktilnost s velikom sposobnošću radnog otvrdnjivanja. Otpornost na trošenje prije kontaktnog trošenja ovisi o intenzitetu otvrdnjavanja površine i postupku otvrdnjavanja tijekom rada [1, 2, 3,]. Budući da se zbog otpornosti abraziji povećava postotak ugljika iznad $1,4 \%$ i više, može se pojaviti problem postizanja homogene austenitne strukture koja bi bila bez zrnaca karbida [4].

Ključne riječi: čelik s manganom; zavarljivost; željeznica

\section{Introduction}

Hadfield Steel is used wherever resistance is required to severe impact or high abrasion. Generally, standard austenitic cast steel which is used for grade railways, contains approximately $1 \%$ of carbon, and $11 \%$ of manganese. The wrought rails are made from pearlitic steel which contains approximately $0,6 \%$ of the carbon, $1,5 \%$ of the manganese and less than $0,5 \%$ of the silicon. On the other hand, the physical properties of these two materials create a problem with the welding process due to different physical and welding properties. The carbide precipitation on the austenitic grain in the Heat-Affected Zone (HAZ) of the Hadfield's steel decreases the mechanical parameters and simultaneously reduces the fracture behaviour, especially fracture toughness, strength or plasticity $[5,11]$. It is a very well-known fact that very fast cooling after the welding process could decrease the carbide formation but on the other hand it could have an effect on sufficient welding quality. Anyway, the rapid cooling process of pearlitic steel creates a martensitic transformation near the fuse line. The high carbon level at the martensite phase brings about a deficiency in plasticity, which is necessary for residual stress relaxation after the cooling process [10]. These two consequences could cause a cold cracking problem in the Heat-Affected Zone. If we apply the preheating process with a controlled cooling speed for the austenitic part of the weld joint, we can improve steel weldability. Generally, the preheating process has an unfavourable influence on the cooling speed, which is important for the austenited parts of welded joint. Nowadays, the mentioned "heterogeneous joint welding technology" is patented in several countries. The welding technology for crossing welds was firstly discovered by an American patent [6] institute and that technology and basic principle for low carbon austenitic steel was used as an interposed connector between the wear resistant high manganese casting steel and carbon rail steel.

The main aim of this article is to find out the specific structural changes of manganese steels, often called Hadfield's steels, caused by thermal and stress influence after the welding technology for the crossing parts on a carbon steel rail. Hadfield's steel is described as steel with optimal wear and hardening properties.

\section{Experimental procedures and used methodology}

The main topic of this article is to analyse the typical welding joints between three different austenitic steels. The first of them is Hadfield's steel for the crossing profile and the second is low carbon stainless steel $(\mathrm{Cr} / \mathrm{Ni}$ content) with a rail profile. The second steel is a compromise between high manganese and carbon rail steel. The last one (ESAB OK Tubrodur 14.71) is used for reprofiling after operational damage. The chemical composition of the investigated steels is shown in Tab. 1.

Table 1 Chemical content of tested steels (wt. \%)

\begin{tabular}{|c|c|c|c|c|}
\hline & \multicolumn{4}{|c|}{ Chemical content (\%) } \\
\hline & $\mathrm{C}$ & $\mathrm{Mn}$ & $\mathrm{Si}$ & $\mathrm{P}$ \\
\hline Hadfield's steel & 1,10 & 11,9 & 0,48 & 0,027 \\
\hline Stainless steel & 0,07 & 0,46 & 0,52 & 0,014 \\
\hline $\begin{array}{c}\text { ESAB OK } \\
\text { Tubrodur 14.71 } \\
\text { (Filler material) }\end{array}$ & 0,04 & 6,2 & 0,51 & 0,016 \\
\hline \multicolumn{4}{|c|}{ Chemical content (\%) } \\
\hline $\begin{array}{c}\text { Hadfield's steel } \\
\text { HAB OK Tubrodur }\end{array}$ & 0,006 & 0,08 & 0,05 & - \\
\hline $\begin{array}{c}\text { 14.71 (Filler } \\
\text { material) }\end{array}$ & 0,016 & 19,4 & 8,22 & - \\
\hline
\end{tabular}


The weld joints for Hadfield's steel and both low carbon stainless steels showed defects in the fusion zone after the machining process. We wanted to find out the real damage and reasons for these defects so we used the following methods:

- Structural and phase analyses - for the fusion zone and thermal affected zones, a study of the structural changes under the effect of thermal and stress welding.

- Chemical - energy diffraction X-ray microanalyses, identification of selected phase imperfections with an influence on the observed damage.

\subsection{Micro-analytical evaluation}

Metallographic study, or metallography, is the imaging of topographical or micro-structural features on tested surfaces. Characteristic features provide information about composition, phase distribution, mechanical and physical properties, thermo-mechanical process history, and defects and failure analysis also. Fig. 1 shows the noticeable primary dendrite morphology of the macro-structure.

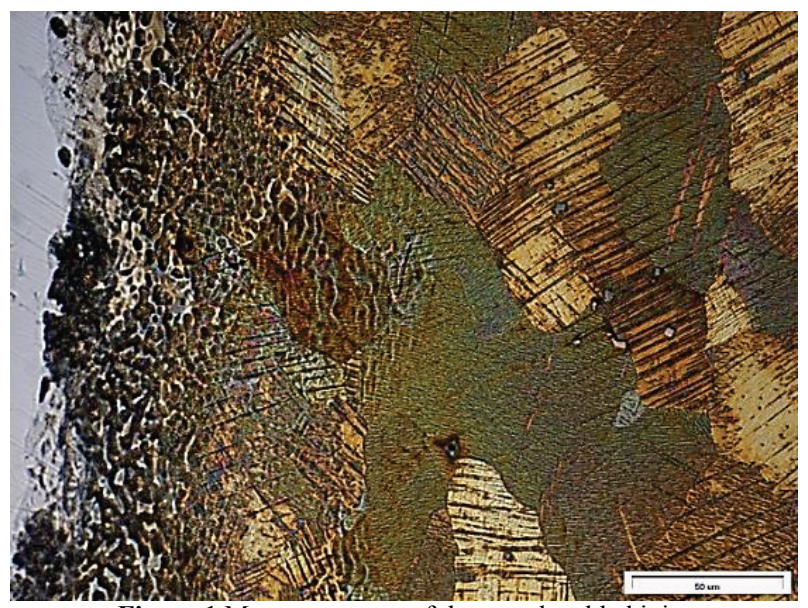

Figure 1 Macro-structure of the tested welded joint

If we want to discover the local material defect, we have to do a structural analysis of the welded line and damaged layers which are connected. The defects in the welded line were founded with a very low number of a residual weld metal if approximately $100 \mu \mathrm{m}$ width. The microscopy location of the intermingled steel, which created the layers or small isles with a lack of chromium and nickel, did not create the cracks and did not make the quality of steel structure worse. The process creates a dislocation structure which is connected with the width intermingled zone. The mentioned dependence can be connected with a difference in the press level along the fusion line during welding, for example the influence of surface roughness of the welded areas. It is proved that the microscopic isles of the contrast phases are created by a dislocation of martensite without carbide precipitation, and it is one of the most important pieces of information for Hadfield's steel when there is indicated some imperfection in the weld joints. The low carbon form of martensite provides a better toughness for the structure. Our testing found only a dislocation with a hardening tendency. As is generally known, the austenite transformation to martensite is created by the intermediate stage of the hexagonal phase $\varepsilon$; the low strain rate increases density; then creates a hexagonal phase; and in the final process during high level deformation there is created the martensite phase, which is called "ferromagnetic phase $\alpha 2$ ". This reaction is related to the stratified flaw energy in analysed grade of $\mathrm{Cr} / \mathrm{Ni}$ steel with the typical very easy dislocation which was created. Generally, a too fast cooling process brings about a stronger strain hardening ability.

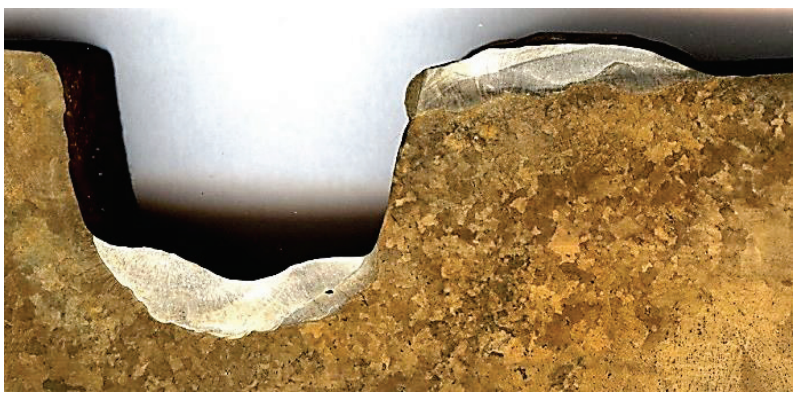

Figure 2 Macro-structure of the tested welded joint (magn. $2 \times$ )

Cracks were noticed across the clad interfaces of welded joints which were made with added material (filler material), SAB OK Tubrodur 14.71. The input heat during the welding process was approximately 8,97 $\mathrm{kJ} / \mathrm{cm}$. The overlay layers were performed on the head and groove of the rail crossing, see Fig. 2. The working conditions for a welding process with Hadfield's steel is a minimal application of input heat and strict adherence to the interpass temperature, maximally $100{ }^{\circ} \mathrm{C}$. The heating and subsequent cooling processes from the annealing temperature cause the excretion of M3C's carbides in the basic matrix under the partial disintegration of austenite to be a fine pearlite. Cementite carbides in a prolonged isothermal holding contain a higher content of manganese between the slats and exclude ferrite which is deprived of manganese. For the reason of carbide precipitation it is necessary to expect a reduction of impact toughness of the basic matrix in the vicinity of the weld. Long years of experience show that phosphorus and sulphur could cause the occurrence of inter-crystalline cracks. Fig. 3 shows the presence of inter-crystalline cracks in the base material.

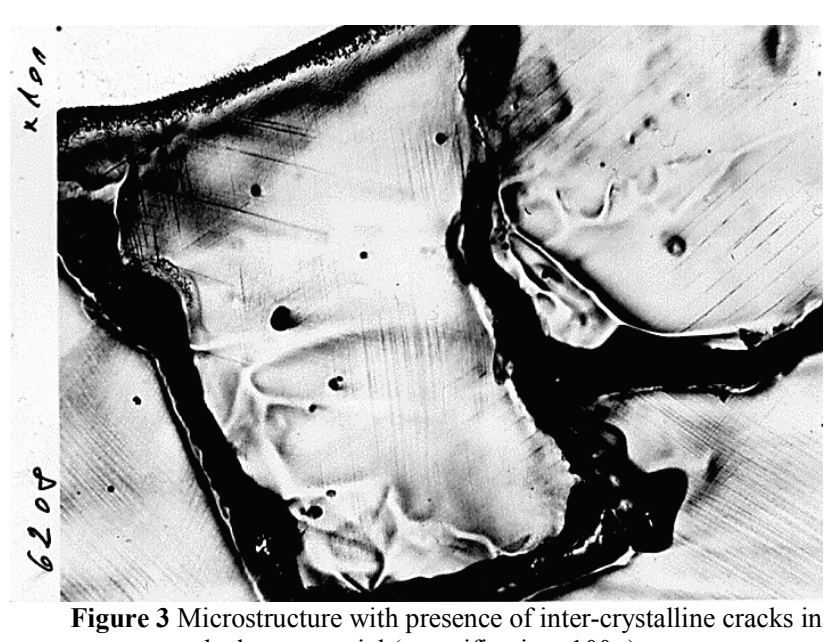
the base material (magnification: $100 \times$ ) 
Local changes in the fusion zone were found and proved by energy dispersion microanalyses. Line analyses showed a higher participation of the alloy's elements of Cr-Mn steel, see Fig.4. The introduced results are with regard to the difference between the melting points of the used steels; the reason is that high manganese steel has a higher melting point than carbon stainless steel.

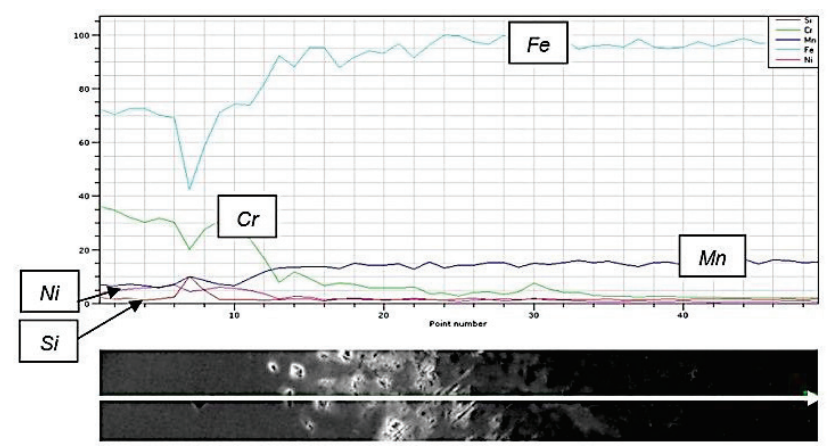

Figure 4 Dependence of the dislocation hardening process on the local chemical differences (magnification: $4000 \times$ )

The introduced results are with regard to the difference between the melting points of the used steels; the reason is that high manganese steel has a higher melting point than carbon stainless steel. Stratified defect energy decreases with a higher manganese percentage and hexagonal phase $\varepsilon$, and martensite consequently arises due to lower plastic deformation. The test showed that along the welding line, which contains approximately $8 \div 9$ $\%$ manganese, a martensite transformation after $20 \%$ deformation is shown.

\subsection{Analysis phase of the Hadfield's steel}

The non-influenced steel volume contained a uniform austenite structure. Generally, the defects are created at the fusion zone on coarsened secondary austenitic grains. Structural and phase analyses discovered the creation process of the shaped carbides, which are connected to local grain decohesion.

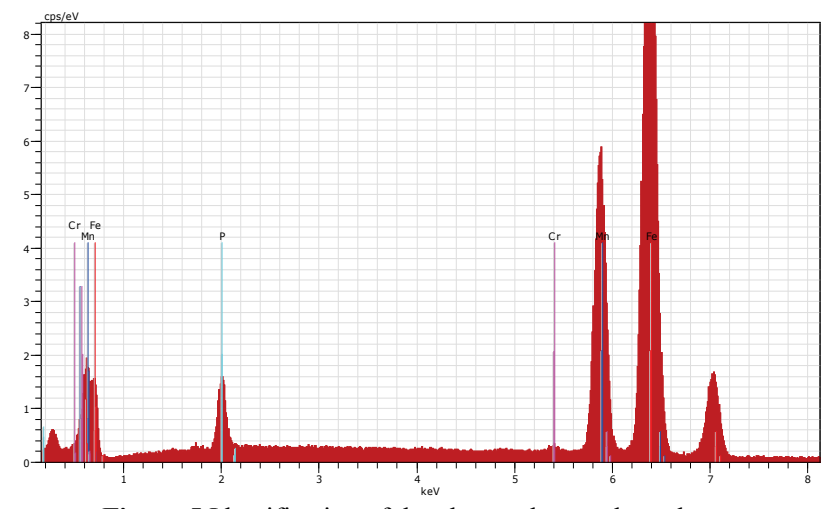

Figure 5 Identification of the observed secondary phases (magnification: $4000 \times$ )

With regard to the interaction there are created two degradation mechanisms. With carbide formation plastic capacity and also fracture toughness are decreased. The chemical analyses verify the creation of phosphide eutectic, which had a globular shape, and a dense cluster formation with a carbide shaped around. A representative example could be seen in Fig. 5. The rate of discovered number of manganese and phosphorus showed the manganese presence [7].

Table 2 Chemical content of the phosphide eutectic (wt. \%)

\begin{tabular}{|c|c|c|c|}
\hline \multicolumn{4}{|c|}{ Chemical content (\%) } \\
\hline $\mathrm{P}$ & $\mathrm{Cr}$ & $\mathrm{Mn}$ & $\mathrm{Fe}$ \\
\hline 4,74 & 0,38 & 24,76 & 70,13 \\
\hline
\end{tabular}

The chemical content of the Hadfield's steel confirmed a satisfactory composition in accordance with worldwide valid standard for Hadfield's steel. The content of the phosphorus in steel structure is approximately below $0,02 \%$; low level is important for reduction of hot tearing but with respect to the possibilities of the casting and the heat treatment process. Sometimes the content of the phosphorus is permitted up to $0,05 \%$.The eutectic line showed the heterogeneous residual phosphorus content after casting process.

\section{General conclusions and discussion}

The common structure of Hadfield's steel is known as part of austenite, secondary carbides and phosphide eutectic and troostite, which is a reddish or greyish mineral that is a variety of willemite in which some of the zinc is replaced by manganese. The homogenous austenite structure is created after a heat treatment process and the structure is created by carbide with a grain boundary orientation or a retained eutectic form.

The renewed eutectic arose during welding loading, which is connected with the cooling phase after the welding process, and it is not sufficient for repressing a typical heterogeneous phase and it creates an increase of the phosphide structure. It is a very unwanted process, which decreases a plastic's ability and creates a decohesion process after the secondary phase.

The chemical composition of the phosphide eutectic has remained uncertain over a long period for the reason of the secondary carbides in the matrix. The microanalysis found the basic constituents of the eutectic to be phosphorus, manganese, iron and carbon. A lot of earlier studies proved that the amount of the phosphide eutectic in Hadfield's steel depends on many technological factors, mainly the cooling phase after casting, the heat treatment process and chemical composition.

In general, a tendency for hot tearing is created in some layers during the primary heterogeneous phases. Mr. Shulik [8] in his work confirmed the same theory that the phosphide phases in the microstructure after air cooling contained less phosphorus percentage than in the analysed case (an investigated influence of $0,016 \%$ phosphorus). At this stage the phosphide eutectic has a globular form and is surrounded by thin shaped carbides. Higher cooling rates could be achieved during pouring into special moulds which are manufactured by the lost wax casting method. This used method could guarantee a lower eutectic formation. The microstructure after casting with $0,051 \%$ content of phosphorus leads to the existence of eutectic in a globular form during the cooling phase which started at $1100{ }^{\circ} \mathrm{C}$. 
The chemical composition and welding parameters for Hadfield's steel have an influence on the susceptibility to cracking at the application of a higher welding parameter than the higher input temperature. The second important parameter is the interpass temperature. These two parameters decrease the inter-crystalline cracks in the base material after the welding areas.

The real volume of phosphorus broke the safe limit for pearlitic steels. Hot tearing had a tendency to increase the sulphur and phosphorus contents, e.g. Ti content can be beneficial in reducing the volume fraction of residual eutectic liquid and so make the casting less prone to hot tearing [9]. It has been proved by the chemical analysis that additional elements had stable, solid carbides. The performed analysis, which was the aim of this article, proved the phosphide phases with carbide formation as a secondary phase in connection with the created welding joint defects in the matrix. The distribution and volume of the detrimental phases are closely connected with the used technological parameters. As we can notice the material is very sensitive to main casting defects, such as hot tearing in very thin zone during complete or partial reaustenitization.

\section{Acknowledgement}

The work reported in the article has been supported by the "Competence Center of Railway Vehicles", Project No. TAČR TE01020038.

\section{References}

[1] Karaman, I.; Sehitoglu, H.; Chumlyakov, Y.; Maier, H.; Kirkeva, I. Extrinsic stacking faults and twinning in Hadfield manganese steel single crystals. // Scripta Mater. 44, 2(2001), pp. 337-343. DOI: 10.1016/S1359-6462(00)00600$\mathrm{X}$

[2] Efstathiou, C.; Sehitoglu, H. Strengthening Hadfield steel welds by nitrogen alloying. // Materials Science and Engineering A. 506, (2009), pp. 174-179. DOl: 10.1016/j.msea.2008.11.057

[3] Efstathiou, C.;Sehitoglu, H. Strain hardening and heterogeneous deformation during twinning in Hadfield steel. // Acta Materialia. 58, (2010), pp. 1479-1488. DOl: 10.1016/j.actamat.2009.10.054

[4] Mohyla, P. Affect of tempering temperatures on mechanical properties of weld joints in low-alloyed creep-resistant steels. // Acta Metallurgica Slovaca. 10, 4(2004), pp. 193200.

[5] Mendez, J.; Ghoreshy, M.; Mackay, W. B. F.; Smith, T. J. N.; Smith,R.W. Weldability of Austenitic Manganese Steel. // Journal of Materials Processing Technology. 153-154, 13(2004), pp. 596-602.

[6] Fucheng, Zhang; Bo, Lv; Baitao, Hu; Yanguo, Li. Flash butt welding of high mangan steel crossing and carbon steel rail. // Material science and engineering A. 454-455, (2007), pp. 288-292. DOI: 10.1016/j.msea.2006.11.018

[7] Chojecki, A.; Telejko, I. Effect of the chemical composition of Fe-Mn-C-P alloys on the brittle-ductile transition temperature in the solidification range. // Steel Res. 63, 10(1992), pp. 447-452.

[8] Shulik, D.; Kamarash, L.; Vilchko, Ya.; Dzugas, P. Phosphide eutectic in a Hadfield steel structure. // Metallovedenie i Termicheskaya Obrabotka Metallow. 2(1992), pp. 2-3. DOI: 10.1007/bf00769871
[9] Zorc, B, Z.; Nagode, A.; Kosec, B.; Kosec, L. Analysis of weld cracking in shot-blasting chambers made of Hadfield steel. // Engineering Failure Analysis. 33, (2013), pp. 4854. DOI: 10.1016/j.engfailanal.2013.04.023

[10] Neslusan, M.; Mrkvica, I.; Cep, R.; Raos, P. Heat Distribution when Nickel Alloy Grinding. // Tehnicki vjesnik-Technical Gazette. 19, 4(2012), pp. 947-951.

[11] Sevcikova, X.; Krejci, L.; Konecna, K. Mechanical and Corrosion Properties of Galvanic Coatings based on Zinc. // METAL 2013: $22^{\text {nd }}$ International Conference on Metallurgy and Materials, pp. 1117-1122.

\section{Authors' addresses}

Eva Schmidova, Prof. Ing. Ph.D.

University of Pardubice, Jan Perner Transport Faculty, Department of Mechanics, Materials and Machine Parts, Studentská 95, 53210 Pardubice 2, Czech Republic E-mail: eva.schmidova@upce.cz

Ivo Hlavaty, Assoc. Prof. Ing. Ph.D.

VSB-TU Ostrava, Faculty of Mechanical Engineering, Department of Mechanical Technology,

17. listopadu 15/2172, 70833 Ostrava, Czech Republic E-mail: ivo.hlavaty@vsb.cz

\section{Petr Hanus, Ing.}

University of Pardubice, Jan Perner Transport Faculty, Department of Mechanics, Materials and Machine Parts, Studentská 95, 53210 Pardubice 2, Czech Republic E-mail: petr.hanus@upce.cz 